\title{
Mantle cell lymphoma with skin involvement
}

\author{
Agnieszka Kalińska-Bieniasㄹ, Bogna Ziarkiewicz-Wróblewska², Cezary Kowalewski ${ }^{1}$, Katarzyna Woźniak ${ }^{1}$
}

${ }^{1}$ Department of Dermatology and Immunodermatology, Medical University of Warsaw, Warsaw, Poland

Head of the Department: Prof. Cezary Kowalewski MD, PhD

2Department of Pathology, Medical University of Warsaw, Warsaw, Poland

Head of the Department: Prof. Barbara Górnicka MD, PhD

Postep Derm Alergol 2015; XXXII (3): 229-234

DOI: $10.5114 /$ pdia.2014.44028

Mantle cell lymphoma $(\mathrm{MCL})$ is a rare disease of the lymphomatoid system arising from mature B lymphocytes and comprises $3-10 \%$ of all non-Hodgkin's lymphoma subtypes and typically involves lymph nodes. According to the guidelines of the World Health Organization-European Organization for Research and Treatment of Cancer (WHO-EORTC), the diagnosis of $\mathrm{MCL}$ should be established on the basis of morphological examination and immunophenotyping with detection of cyclin D1 protein overexpression and/or chromosomal translocation $\mathrm{t}(11,14)(\mathrm{q} 13 ; \mathrm{q} 32)$ of the CCND1 gene [1]. Histologically MCL is composed of diffuse or nodular proliferations of B lymphocytes in the mantle zone of lymphoid follicles in lymph nodes with characteristic immunophenotypical pictures positive for B-cell markers, like CD79a, CD19, CD20, CD22 and CD5 as well as usually negative for CD10, CD23 and bcl-6. The blastoid variant of MCL develops in 10-30\% of patients with classic MCL [2]. This type of lymphoma joints two inauspicious clinical features: incurability and quick progression. At the time of diagnosis, the disease is usually in the advanced stage with a frequent generalized lymphadenopathy, splenomegaly and the bone marrow, blood or gastrointestinal involvement (stage III, IV in Ann Arbor scale) [3]. The disease generally involves lymph nodes but primary extranodal localization may also occur especially in the bone marrow, spleen, gastrointestinal tract and Waldeyer's ring. In the classification of WHO-EORTC, mantle cell lymphoma is listed as an extracutaneous lymphoma secondarily involving the skin. However, skin involvement, if present, is usually common in the widespread disease [4]. The primary skin involvement in MCL is extremely rare and controversial [5].

We report a case of a patient with $M C L$ secondary involving the skin and review of the literature of cutaneous involvementinpreviously reported cases of $\mathrm{MCL}$.
A 63-year-old woman referred to the Department of Dermatology presented with severe thick erythematous infiltrations located on all her face and the ears as well as hyperpigmentations on the upper part of the trunk. Skin lesions on the face started as erythema resembling photosensitivity and progressively enlarged (Figures 1 A-B). On admission the patient has had the dryness of the oral mucosa, difficulties in speaking, increased dyspnea for several weeks. The generalized lymphadenopathy was observed. Laboratory abnormalities included an elevated level of leucocyte count of $24000 / \mathrm{mm}^{3}$ with lymphocytosis of $75 \%$ and anemia with hemoglobin of $7.7 \mathrm{~g} / \mathrm{dl}$. Mantle cell lymphoma was diagnosed in a skin biopsy specimen, lymph node and bone marrow. Skin biopsy taken from the ear showed a numerous diffuse lymphoid infiltrate in dermal and subcutaneous tissue with a grenz zone with sparing the epidermis. Neoplastic cells were intermediate to large size with irregular and hyperchromatic nuclei with increased mitotic activity (Figure 2 A). Histopathological examination taken from the lymph node showed numerous lymphoid infiltrates (Figure 2 D) and histopathology from the bone narrow revealed infiltration of lymphoma covered more than a half of the tissue of bone marrow (Figure $2 \mathrm{G}$ ). Immunohistochemically, the tumor cells from the skin, lymph node and bone marrow were positive for CD20, CD5 and were negative for CD3 marker (Figures 2 B, C, E). In the lymph node and bone marrow, CD23 staining was negative (figure not shown). The proliferation index measured by immunostaining with MIB1 was positive in $50 \%$ of the cells of the lymph node (Figure $2 \mathrm{~F}$ ). Immunophenotypic analysis by flow cytometry on bone marrow aspirate specimens showed the presence of CD5, CD19, CD20 markers on over $90 \%$ of the cells and clonal expression of immunoglobulin $\kappa$ and $\lambda$ light

Address for correspondence: Agnieszka Kalińska-Bienias MD, PhD, Department of Dermatology and Immunodermatology, Medical University of Warsaw, 82 a Koszykowa St, 02-008 Warsaw, Poland, phone: +48 606618 564, fax: +48 5022104 , e-mail: agnieszka.kalinska@interia.pl

Received: 5.01.2014, accepted: 19.05.2014. 


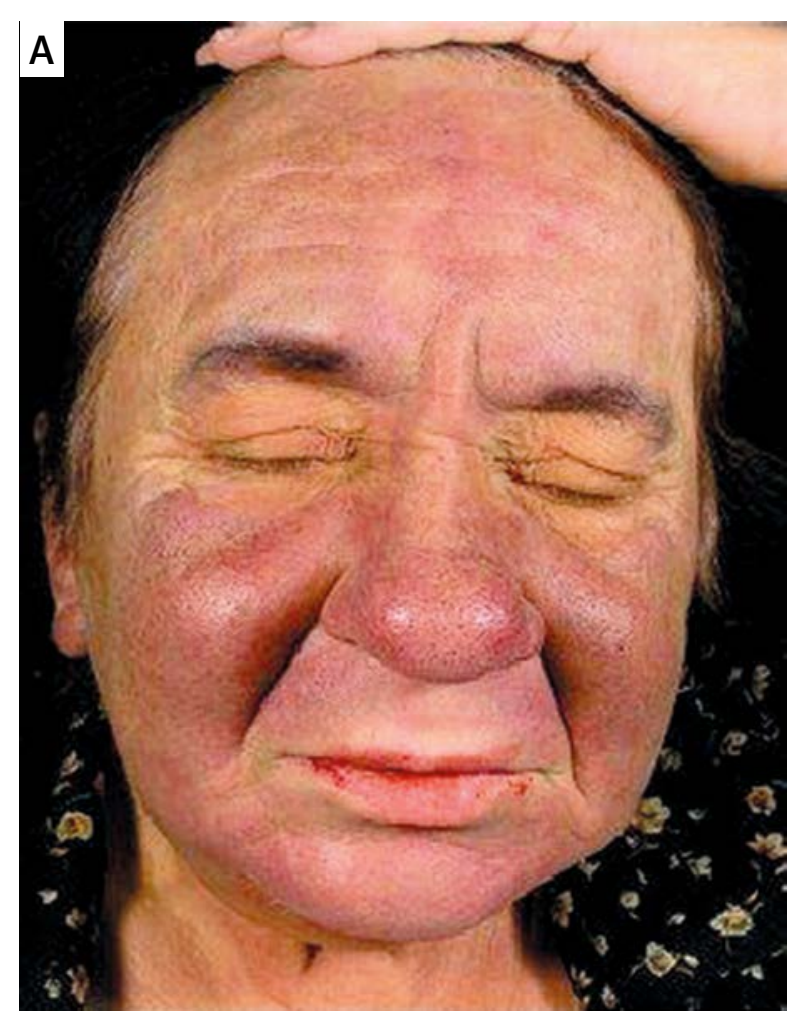

chains. Cyclin D1 was strongly expressed (Figure $2 \mathrm{H}$ ). Computed tomography (CT) scans of the neck and chest showed a tumor lesion in the larynx and enlarged lymph nodes along cervical vessels and the package of lymph nodes in the mediastinum. Computed tomography (CT) scans of the abdomen and pelvis revealed enlarged periaortic and inguinal lymph nodes as well as in the mesentery of the intestine. On the basis of the histological and immunohistochemical data, the diagnosis of $M C L$ was made and in the staging evaluation the patient presented with Ann Arbor stage IV D/B with lymphadenopathy and the bone marrow involvement. The patient was referred to the Hematology Department, where she received the CHOP (cyclophosphamide, doxorubicin, vincristine, prednisone) chemotherapy. After five cycles of the chemotherapy the patient achieved a partial remission of skin lesions and lymphadenopathy and complete remission of dyspnea. At that time her general condition improved. After 7 months there was the recurrence of the disease and despite receiving aggressive multiagent chemotherapy DHAP (dexamethasone, cytarabine, cisplatin), the chemo-resistance was present and the patient died after several weeks (1 year after diagnosis of $\mathrm{MCL}$ ).

Herein we report a case of mantle cell lymphoma with secondary skin involvement with typical histopathologic and immunohistochemical findings in the skin, lymph nodes and bone marrow. On admission to the department the patient presented confluent thick erythematous infiltrations located on theface and ears. So far, only 24 such cases with MCL and skin involvement have been

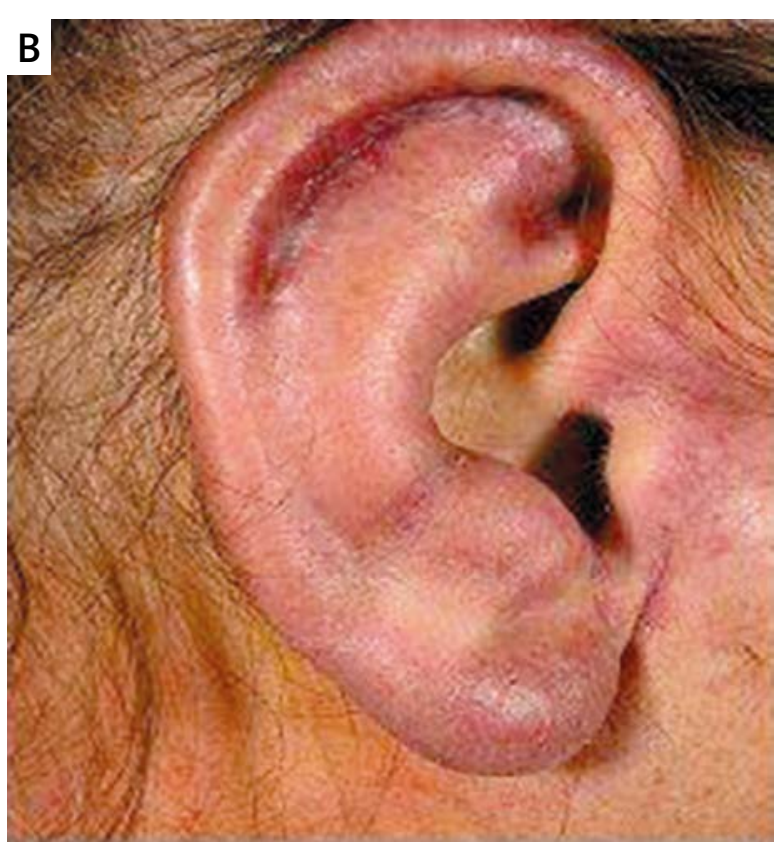

Figure 1. Confluent skin infiltration on the face (A) and the ear (B)

described in the English language literature. The clinical features are listed in Table 1 . Out of 24 reported patients only one patient had a skin lesion located on the ears and in 8 cases, skin lesions were present on the face. It needs to be stressed that the most common affected area was the trunk (11 patients) followed by the face, and arms, thighs, legs and abdomen. In the current patient, skin lesions started 6 months before and initially were recognized as photodermatosis. To the best of our knowledge, we reported the first patient presenting a confluent skin lesion infiltrating all the face, forehead and ears resembling facies leonine. In the previously published cases, skin lesions mainly consisted of nodules, macules, tumoral plaques and subcutaneous infiltrations. Our patient presented confluent tumoral infiltrations. The average age of the patients with cutaneous $M C L$ is 64.4 years (range: 22-89 years) what complies with our patient's age -63 years. The ratio of male to female was $19: 5$. Although skin involvement in MCL is rare in general, it is observed in $17 \%$ of patients with IV stage disease. In our patient, systemic symptoms preceded skin changes [5]. The existence of primary cutaneous MCL is controversial. According to the EORTC-WHO definition, the diagnosis of primary cutaneous lymphoma may be established if there is no evidence of extracutaneous involvement at the time of diagnosis or during 6 months of follow-up with proper staging [6]. So far in the literature there have been reported only 6 patients with cutaneous MCL without any evidence of systemic involvement (Table 1$)$. The age of these patients ranges from 22 to 83 and the most 

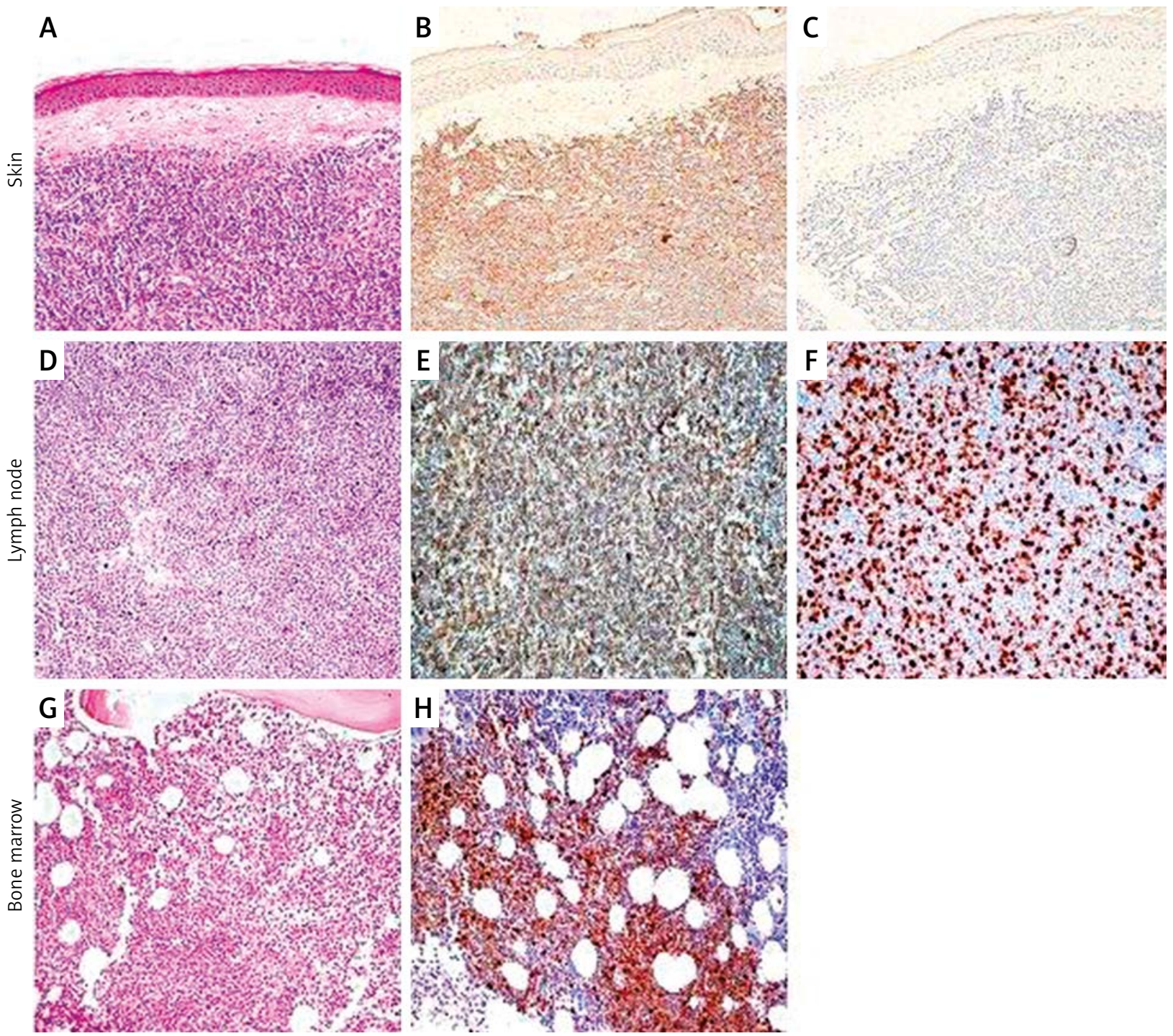

Figure 2. Histological and immunohistochemical findings of the patient's skin (A-C), lymph node (D-F) and bone marrow $(\mathrm{G}-\mathrm{H})$ : A - proliferation of small to medium-sized atypical lymphoid cells (hematoxylin-eosin stain, 100x), B - expression of CD20 by neoplastic cells (100x), C - no expression of CD3 (100x), D - diffuse proliferation of lymphoid cells (hematoxylin-eosin stain, 200x), E - expression of CD5 by neoplastic cells (200x), F - staining with antibody to Ki 67 (200x), G - diffuse proliferation of lymphoid cells (hematoxylin-eosin stain, 200x), H - neoplastic cells expressed cyclin D1 (200×)

frequent localization was the thigh or breast and the lesions were described as solid nodules.

An interesting cutaneous phenomenon in MCL described in the literature is exaggerated reactions to insect bites. It seems to be over-reactive rather than malignancy because the tumor cells were not detected in these cases [7]. Our patient presented neither clinically nor histopathologically skin symptoms typical of an insect bite.

The immunohistochemical profile of MCL of our patient was comparable to that of all published cases. On immunophenotypical analyses tumor cells were positive for B-cell markers: CD20, CD22, CD5 and negative for CD3, CD10 and CD23. A characteristic feature for MCL is mutation of the $\mathrm{t}(11 ; 14)(\mathrm{q} 13 ; \mathrm{q} 32)$ translocation which causes the juxtaposition of the CCND-1 gene on chromosome 11 with the immunoglobulin heavy chain gene on chromosome 14 leading to over-expression of cyclin D1. This protein acts as a positive signal for the transition from G1 to S phase and stimulates cells to proliferation. It is also known that cyclin D1 is characteristic of $\mathrm{MCL}$ and is expressed in more than $60-70 \%$ of cases of $\mathrm{MCL}$ (even almost all cases in some publications) but also can be positive in $4 \%$ of B-cell chronic lymphocytic leukemia/small lymphocytic lymphoma (B-CLL/SLL) [8]. On the other hand, both lymphomas usually show a different pattern of expression of cyclin Dlin the lymph node. In MCL, the expression of cyclin D1is rather diffuse and 
Table 1. Reported cases of mantle cell lymphoma with cutaneous involvement

\begin{tabular}{|c|c|c|c|c|c|c|c|c|}
\hline No. & Authors & $\begin{array}{c}\text { Sex/ } \\
\text { age }\end{array}$ & Localization & $\begin{array}{l}\text { Type of skin } \\
\text { lesions }\end{array}$ & $\begin{array}{c}\text { Primary/ } \\
\text { secondary } \\
\text { skin MCL }\end{array}$ & $\begin{array}{c}\text { Organ } \\
\text { involvement }\end{array}$ & Stage & Prognosis and course \\
\hline 1 & $\begin{array}{c}\text { Ellison et al. } \\
1987 \text { [10] }\end{array}$ & $M / 66$ & Temple & Macules & Secondary & $\begin{array}{l}\text { LN, liver, spleen, } \\
\text { lung, pleural } \\
\text { cavity, CNS }\end{array}$ & IV & $\begin{array}{c}\mathrm{D} \\
\text { (55 days } \\
\text { after hospitalization) }\end{array}$ \\
\hline 2 & $\begin{array}{c}\text { Geerts et al. } \\
1994 \text { [11] }\end{array}$ & $\mathrm{F} / 65$ & Forehead & Nodules & Secondary & LN, BM & IVA & $\begin{array}{c}\text { D } \\
\text { (11 months } \\
\text { after diagnosis) }\end{array}$ \\
\hline 3 & $\begin{array}{c}\text { Geerts et al. } \\
1994 \text { [11] }\end{array}$ & $\mathrm{F} / 77$ & $\begin{array}{l}\text { Back, breast, } \\
\text { arm }\end{array}$ & Tumoral plaques & Secondary & Bronchus wall & IVA & $\begin{array}{c}\text { D } \\
\text { (1.5 years } \\
\text { after diagnosis) }\end{array}$ \\
\hline 4 & $\begin{array}{c}\text { Bertero et al. } \\
1994 \text { [12] }\end{array}$ & $M / 51$ & Breast & $\begin{array}{l}\text { Subcutaneous } \\
\text { nodule }\end{array}$ & Secondary & LN, liver, spleen & IVA & $\begin{array}{c}\mathrm{A} \\
\text { (17 years, after onset) }\end{array}$ \\
\hline 5 & $\begin{array}{c}\text { Bertero et al. } \\
1994 \text { [12] }\end{array}$ & $\mathrm{F} / 78$ & Breast, back & Nodules & Primary & None & $\mathrm{IE}$ & $\begin{array}{c}\text { D } \\
\text { (3 years, } \\
\text { after diagnosis) }\end{array}$ \\
\hline 6 & $\begin{array}{c}\text { Bertero et al. } \\
1994 \text { [12] }\end{array}$ & $M / 43$ & $\begin{array}{l}\text { Back, face, } \\
\text { arm }\end{array}$ & Infiltrated plaques & Secondary & LN, liver, spleen & IVA & A \\
\hline 7 & $\begin{array}{c}\text { Bertero et al. } \\
1994 \text { [12] }\end{array}$ & $M / 22$ & Breast & Nodules & Primary & None & IE & A \\
\hline 8 & $\begin{array}{l}\text { Marti et al. } \\
2001[13]\end{array}$ & $\mathrm{F} / 61$ & Abdomen & Tumoral plaque & Secondary & LN, BM, tonsils & IV A & $\begin{array}{c}\text { D } \\
\text { (15 months, } \\
\text { after diagnosis) }\end{array}$ \\
\hline 9 & $\begin{array}{c}\text { Moody et al. } \\
2001[3]\end{array}$ & $M / 47$ & Ear & Nodules & Secondary & LN, BM & IV A & $\begin{array}{c}\mathrm{A} \\
\text { (3 years, after onset) }\end{array}$ \\
\hline 10 & $\begin{array}{l}\text { Dubus et al. } \\
2002[14]\end{array}$ & $M / 56$ & Breast, back & $\begin{array}{l}\text { Erythematous } \\
\text { papules }\end{array}$ & Secondary & LN, BM, PB & IV A & $\begin{array}{c}\text { D } \\
\text { (1 year, } \\
\text { after treatment) }\end{array}$ \\
\hline 11 & $\begin{array}{l}\text { Dubus et al. } \\
2002[14]\end{array}$ & $M / 89$ & $\begin{array}{l}\text { Breast, back, } \\
\text { abdomen }\end{array}$ & $\begin{array}{l}\text { Infiltrated purpuric } \\
\text { papules }\end{array}$ & Secondary & LN, BM, PB & IV A & $\begin{array}{c}\text { D } \\
\text { (5 days, } \\
\text { after diagnosis) }\end{array}$ \\
\hline 12 & $\begin{array}{l}\text { Dubus et al. } \\
2002[14]\end{array}$ & $M / 72$ & $\begin{array}{l}\text { Face, breast, } \\
\text { arm, axilla }\end{array}$ & $\begin{array}{l}\text { Subcutaneous } \\
\text { nodules }\end{array}$ & Secondary & LN, BM & IV A & $\begin{array}{c}\text { A } \\
\text { (1 year, } \\
\text { after treatment) }\end{array}$ \\
\hline 13 & $\begin{array}{l}\text { Sen et al. } \\
2002[6]\end{array}$ & $M / 85$ & Leg & Macular rash & Secondary & $\begin{array}{l}\mathrm{LM}, \mathrm{BM}, \text { buccal } \\
\text { mucosa }\end{array}$ & IV B & $\begin{array}{c}\text { D } \\
\text { (20 months, } \\
\text { after onset) }\end{array}$ \\
\hline 14 & $\begin{array}{l}\text { Sen et al. } \\
2002[6]\end{array}$ & $M / 76$ & Thigh & Solitary nodule & Primary & None & IE & $\begin{array}{c}\text { A } \\
\text { (30 months, } \\
\text { after onset) }\end{array}$ \\
\hline 15 & $\begin{array}{l}\text { Sen et al. } \\
2002[6]\end{array}$ & $M / 56$ & Chest & Nodules & Secondary & $\mathrm{BM}, \mathrm{Gl}$ & IV A & $\begin{array}{c}\text { A } \\
\text { (21 months, } \\
\text { after onset) }\end{array}$ \\
\hline 16 & $\begin{array}{l}\text { Sen et al. } \\
2002[6]\end{array}$ & $M / 57$ & Legs & Maculopapular rash & Secondary & LN, BM, PB & IV B & $\begin{array}{c}\mathrm{D} \\
\text { (9 months, after onset) }\end{array}$ \\
\hline 17 & $\begin{array}{l}\text { Sen et al. } \\
2002[6]\end{array}$ & $M / 61$ & $\begin{array}{l}\text { Flank, back, } \\
\text { thigh }\end{array}$ & Plaques & Secondary & $\begin{array}{l}\text { LN, BM, PB, } \\
\text { leptomeninges }\end{array}$ & IV B & $\begin{array}{c}\mathrm{D} \\
\text { (15 months, } \\
\text { after onset) }\end{array}$ \\
\hline 18 & $\begin{array}{l}\text { Motegi et al. } \\
2006 \text { [9] }\end{array}$ & $M / 62$ & $\begin{array}{l}\text { Back, upper } \\
\text { extremities, } \\
\text { chest, penis }\end{array}$ & $\begin{array}{l}\text { Nodules, erythema, } \\
\text { skin ulcers }\end{array}$ & Secondary & $\begin{array}{l}\text { LN, spleen, buccal } \\
\text { mucosa, hard } \\
\text { palate mucosa }\end{array}$ & IV & $\begin{array}{c}\text { A } \\
\text { (4 months } \\
\text { after diagnosis) }\end{array}$ \\
\hline
\end{tabular}


Table 1. Cont.

\begin{tabular}{|c|c|c|c|c|c|c|c|c|}
\hline No. & Authors & $\begin{array}{l}\text { Sex/ } \\
\text { age }\end{array}$ & Localization & $\begin{array}{l}\text { Type of skin } \\
\text { lesions }\end{array}$ & $\begin{array}{l}\text { Primary/ } \\
\text { secondary } \\
\text { skin MCL }\end{array}$ & $\begin{array}{c}\text { Organ } \\
\text { involvement }\end{array}$ & Stage & Prognosis and course \\
\hline 19 & $\begin{array}{l}\text { Goteri et al. } \\
2007[15]\end{array}$ & $M / 70$ & $\begin{array}{c}\text { Back, left } \\
\text { shoulder, arm }\end{array}$ & Nodules & Secondary & $\begin{array}{l}\text { LN, coexistence } \\
\text { with primary } \\
\text { cutaneous } \\
\text { follicular } \\
\text { lymphoma }\end{array}$ & ND & A \\
\hline 20 & $\begin{array}{c}\text { Estrozi et al. } \\
2009[2]\end{array}$ & $M / 72$ & $\begin{array}{l}\text { Temporal } \\
\text { region }\end{array}$ & Nodule & Primary & None & IE & $\begin{array}{c}\text { A } \\
\text { (6 months, } \\
\text { after diagnosis) }\end{array}$ \\
\hline 21 & $\begin{array}{l}\text { Canpolat et al. } \\
2010 \text { [1] }\end{array}$ & $F / 49$ & $\begin{array}{c}\text { Face, } \\
\text { shoulders, } \\
\text { back, chest }\end{array}$ & $\begin{array}{l}\text { Erythematous } \\
\text { papules }\end{array}$ & Secondary & LN, BM, spleen & IV B & $\begin{array}{c}\text { D } \\
\text { (4 months, after onset) }\end{array}$ \\
\hline 22 & $\begin{array}{l}\text { Zattra et al. } \\
2011[16]\end{array}$ & $M / 77$ & All body areas & Nodules, plaques & Primary & None & IE & $\begin{array}{c}\text { A } \\
\text { (28 months, } \\
\text { after diagnosis) }\end{array}$ \\
\hline 23 & $\begin{array}{l}\text { Lynch et al. } \\
2012[5]\end{array}$ & $M / 83$ & Thighs & Nodules & Primary & None & IE & $\begin{array}{c}\text { D } \\
\text { (2 months, } \\
\text { after diagnosis) }\end{array}$ \\
\hline 24 & $\begin{array}{l}\text { Phelps et al. } \\
2013[4]\end{array}$ & $M / 71$ & Cheek & Papules & Secondary & Tonsil, tongue & ND & Unknown \\
\hline
\end{tabular}

LN-lymph nodes, BM - bone marrow, $P B$ - peripheral blood, GI - gastrointestinal tract, CNS - central nervous system, A-alive, D - dead, ND - not determined.

comprises almost all tumor cells as distinct from CLL/ $\mathrm{SLL}$ in which only the lymphoproliferative central zone is expressed. To differentiate between BCLL/SLL and MCL overexpression of CD23 is proved to be important. In our case the results of negative CD23 staining in the lymph node and positive cyclin D1 make it possible to exclude of BCLL/SLL. In the differential diagnosis we also excluded other B-cell lymphomas such as marginal zone lymphoma and follicular lymphoma. In our patient the disease was widespread at the time of diagnosis but skin lesions were the first problem noticed by the patient. Of the 24 cases described in the English literature, 19 patients had systemic disease at the time of diagnosis with involvement of the lymph nodes and the marrow bone. Most of the patients also had extracutaneous manifestations such as lymph nodes, bone marrow or gastrointestinal tract and were classified as stage IV. Patients who developed skin lesions with widespread MCL typically had a poor diagnosis. Although they had received aggressive chemotherapy, no good reaction was observed and many of patients died. In reported cases, 11 patients achieved a complete remission and no recurrence was observed during a follow-up period.

In conclusion, $M C L$ is a rare lymphoma and if skin is involved this always suggests dissemination of the disease. Interestingly, in most published cases skin involvement was the first complaint leading to a visit at the dermatologist's. Therefore, it is important to remember that skin involvement may be the first manifestation of $M C L$ and the dermatologist may be the first-line doctor establishing the diagnosis.

\section{Conflict of interest}

The authors declare no conflict of interest.

\section{References}

1. Canpolat F, Tas E, Albayrak SA, et al. Cutaneous presentation of mantle cell lymphoma. Acta Derm Venereol 2010; 90: 548-50.

2. Estrozi B, Sanches JA, Varela PC, et al. Primary cutaneous blastoid mantle cell lymphoma - case report. Am J Dermatopathol 2009; 31: 398-400.

3. Moody BR, Bartlett NL, George DW, et al. Cyclin D1 as an aid in the diagnosis of mantle cell lymphoma in skin biopsies: a case report. Am J Dermatopathol 2001; 23: 470-6.

4. Phelps A, Gorgan M, Elaba Z, et al. CD10-positive blastoid mantle cell lymphoma with secondary cutaneous involvement. J Cutan Pathol 2013; 40: 765-7.

5. Lynch DW, Verma R, Larson E, et al. Primary cutaneous mantle cell lymphoma with blastic features: report of a rare case with special reference to staging and effectiveness of chemotherapy. J Cutan Pathol 2012; 39: 449-53.

6. Sen F, Medeiros LJ, Lu D, et al. Mantle cell lymphoma involving skin: cutaneous lesions may be the first manifestation of disease and tumors often have blastoid cytologic features. Am J Surg Pathol 2002; 26: 1312-8.

7. Khamaysi Z, Dodiuk-Gad RP, Weltfriend S, et al. Insect bitelike reaction associated with mantle cell lymphoma: clinicopathological, immunopathological, and molecular studies. Am J Dermatopathol 2005; 27: 290-5.

8. Asaad NY, Abd El-Wahed MM, Dawoud MM. Diagnosis and prognosis of B-cell chronic lymphocytic leukemia/small lymphocytic lymphoma (B-CLL/SLL) and mantle cell lymphoma (MCL). J Egypt Natl Canc Inst 2005; 17: 279-90.

9. Motegi S, Okada E, Nagai Y, et al. Skin manifestation of mantle cell lymphoma. Eur J Dermatol 2006; 16: 435-8. 
10. Ellison DJ, Turner RR, Van AR, et al. High-grade mantle zone lymphoma. Cancer 1987; 60: 2717-20.

11. Geerts ML, Busschots AM. Mantle-cell lymphomas of the skin. Dermatol Clin 1994; 12: 409-17.

12. Bertero M, Novelli M, Fierro MT, et al. Mantle zone lymphoma: an immunohistologic study of skin lesions. J Am Acad Dermatol 1994; 30: 23-30.

13. Marti RM, Campo E, Bosch F, et al. Cutaneous lymphocyte-associated antigen (CLA) expression in a lymphoblastoid mantle cell lymphoma presenting with skin lesions. Comparison with other clinicopathologic presentations of mantle cell lymphoma. J Cutan Pathol 2001; 28: 256-64.

14. Dubus P, Young P, Beylot-Barry M, et al. Value of interphase FISH for the diagnosis of $\mathrm{t}(11: 14)(\mathrm{q} 13 ; \mathrm{q} 32)$ on skin lesions of mantle cell lymphoma. Am J Clin Pathol 2002; 118: 832-41.

15. Goteri G, Rupoli S, Stramazzotti D, et al. Coexistence of two discordant B-cell lymphomas in the skin and lymph node: report of a case with primary cutaneous follicle-center lymphoma and nodal mantle-cell lymphoma. Br J Dermato 2007; 157: 629-31.

16. Zattra E, Zambello R, Marino F, et al. Primary cutaneous mantle cell lymphoma. Acta Derm Venereol 2011; 91: 474-5. 